Supplement of Biogeosciences, 14, 541-557, 2017

http://www.biogeosciences.net/14/541/2017/

doi:10.5194/bg-14-541-2017-supplement

(C) Author(s) 2017. CC Attribution 3.0 License.

(c) (i)

Supplement of

\title{
Extreme flood impact on estuarine and coastal biogeochemistry: the 2013 Elbe flood
}

Yoana G. Voynova et al.

Correspondence to: Yoana G. Voynova (yoana.voynova@hzg.de)

The copyright of individual parts of the supplement might differ from the CC-BY 3.0 licence. 
a
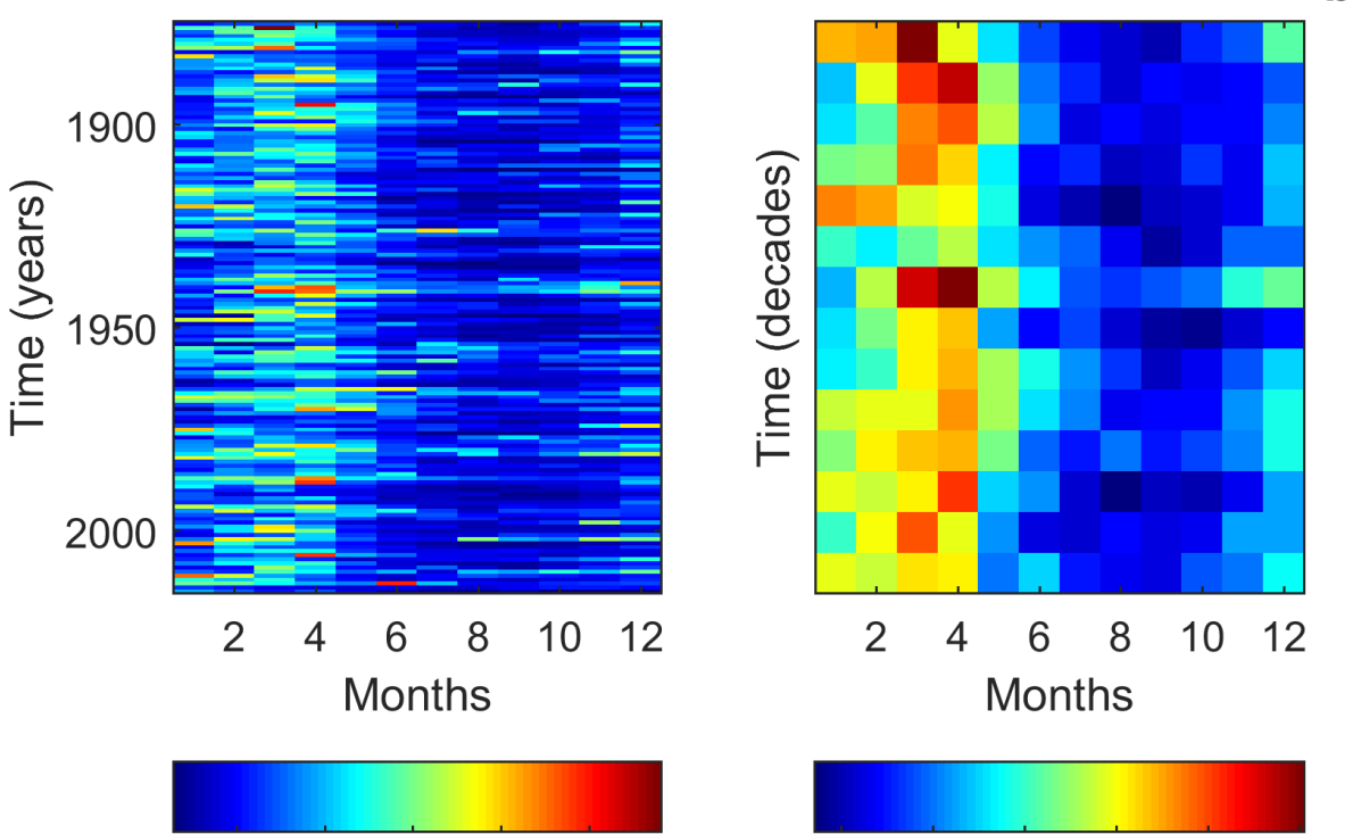

5001000150020002500

Discharge $\left(\mathrm{m}^{3} \mathrm{~s}^{-1}\right)$

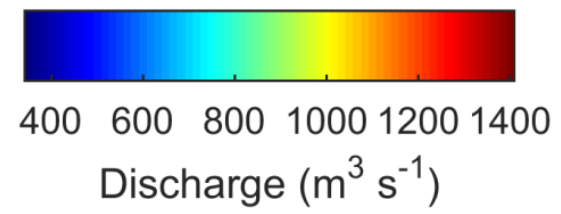

Fig. S1. a. Monthly Neu Darchau station discharge for every year from 1875 to 2015 . Note the 2013 June discharge signal in red. b. Decadal discharge from Neu Darchau, averaged by month. Record used for decadal averaging extends only between 1875 and 2015, in order to separate the data in decadal intervals. 


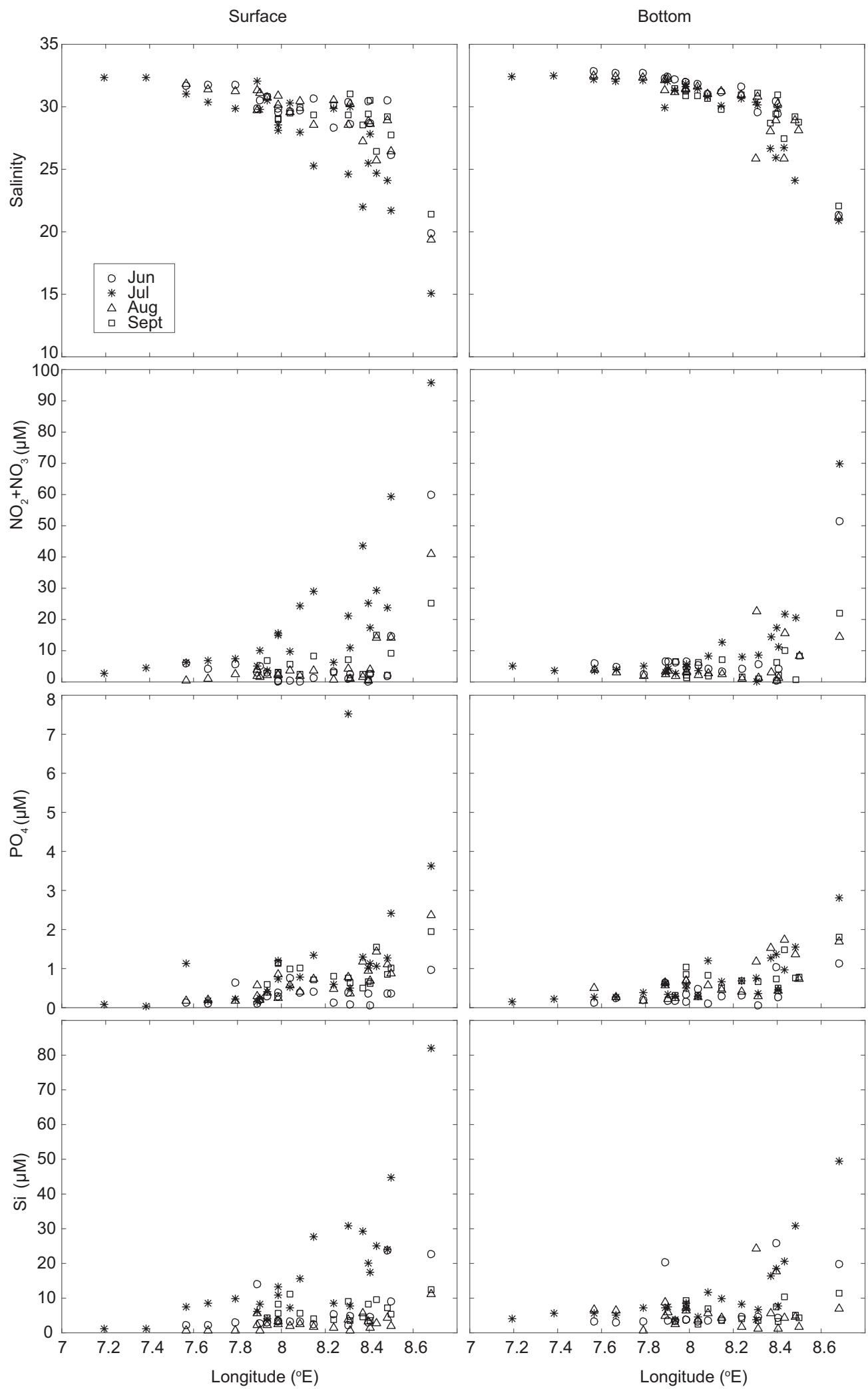

Fig. S2. Surface (left panels) and bottom (right panels) salinity, nitrate + nitrite $\left(\mathrm{NO}_{2}+\mathrm{NO}_{3}\right)$, phosphate $\left(\mathrm{PO}_{4}\right)$, and silicate (Si) data for 4 sampling dates in 2013: June 4-6 (circles), July 2-4 (stars), August 6-8 (triangles), and September 4-5 (squares). 